\title{
Role of Representations and Visual Images in Foreign Policy Decision Making and Constituting of Identities: Turkish Foreign Policy Towards the Palestinian Issue as a Case ${ }^{1}$
}

\author{
Tayyar Ar1 ${ }^{1}$ Eman Sultan ${ }^{2 *}$ \\ 1. Prof. Dr., Head of Department of International Relations, School of Management and Economics, \\ Uludag University, Gorukle Campus, 16059, Nilufer, Bursa, Turkey. \\ 2. $\mathrm{PhD}$. International Relations, Uludag University, Bursa, Turkey. \\ * E-mail of the corresponding author: eman.y.a.sultan@gmail.com
}

\begin{abstract}
This paper discusses how representations and visual images consider a significant factor that led the Turkish foreign policy towards the Palestinian issue during the Justice and Development Party (JDP) era. Discourse theory of Foucault and other theorists, which is part of post-structuralism will be used to show how representations and discursive practices are communicating truth within discourse formation, and reflect a reality to the policy makers, leading to actions and to rising up of other discursive practices taken by the leaders of the Turkish government, in turn, these discursive practices entitled new role identity for Turkey among the Palestinians, and the oppressed people in Islamic and neighbor countries. Three case studies about Israeli violation of human rights in the occupied Palestinian territories will be used to show how photographs and media problematized, socialized and politicized some Israeli violations. While other case will be used to show how some issues face more violations by Israel, but they are not reached by media and their reality is not reflected by representations, consequently these humanitarian cases became unknown and actions that must be taken towards them are unthinkable.
\end{abstract}

Key words: Representations, discursive practices, discursive formation, visual images, media, Turkish Foreign Policy, Arab-Israeli conflict.

DOI: $10.7176 /$ IAGS/81-05

Publication date:March $31^{\text {st }} 2020$

\section{Introduction}

The Palestinian conflict is one of the serious issues that occupies a position in the foreign policy agenda of most of the world countries, the leaders and foreign policy makers of these countries follow different strategies to contribute in solving the issue, and they try to reach the real information in their policy making through sending delegations and opening representative offices in the conflict area. In spite of that, the media and visual images that represent the Arab-Israeli conflict have a big effect on the foreign policy making, while, these representatives are affected by the discursive framework that dominate the media sector, for example, the journalist always tries to take images that reflect the violation of human rights especially the images that show the oppression against children, since they are the most images that stimulates the sympathy of the world, and that is the discursive framework which dominates the media work towards the Palestinian issue. On the other hand, when the leaders of the world take an action according to what they saw in the media their response may create an effect constituting their role or social identity in the region. This paper will show how some events in the conflict area are reached by media and politicized and led to constitution of role identity of the leaders, while other issues still marginalized and unconsidered in the policies of the states, since they are not reached by the media to hands of the policy makers. The cases that are used in this research are images of three children who were exposed to the Israeli violation for a while, their pictures circulated by media and thanks to these pictures they became "Symbols of the Palestinian Resistance", and their pictures provided the opportunity for the leaders of the world to show their support for the Palestinian issue, here the response of the Turkish President Recep Tayyep Erdogan is used as an example. The researcher made a visit to other places in the Palestinian lands which their people are exposed to daily and sever violation of human right by the Israeli government, but their situation did not have the opportunity to be circulated by social media and did not reached to the hand of the Turkish leaders and the policy makers, so it still marginalized and absent in the foreign policy agenda of donor countries. This paper starts by a theoretical part, explaining visual images and representative theories as a part of discourse

\footnotetext{
${ }^{1}$ This paper is part of $\mathrm{PhD}$ research thesis in title of "The Analysis of the Turkish Foreign Policy towards the Palestinian Issue in JDP Era, within the Context of Constructivism and Post-Structuralism”, 2020.
} 
theories that are the focus of post-structuralism, talking about media and discourse as well as the relation between discourse and identity. the second part is talking about role of discourse and media in problematizing and socializing of the Palestinian issue in the Turkish Foreign Policy.

\section{Theoretical Context: "Discourse and Representation Theories Basically Drawn from Foucault's Discourse Theory, which is a part of Post-structuralism"}

Representation and discourse theories are part of Post-structuralist theory which has emerged in France during 1960s to1970s, by main contributions of two philosophers who are Michel Foucault and Jacques Derrida, Foucault focused in his works on power and knowledge, discourse, the suppression of the individual to suprapersonal authority, in addition to his focus on subject and the role of the author (Patterson, 1989, p. 84), (Hall, 1997, p. 43). While Derrida's works focused on deconstruction which used as a method to publicize meanings and interpretations which are not intentionally deliberated by the author (Patterson, 1989, p. 85). However, conceptualization of discourse by Foucault formed a basic ground upon which many scholars depends in their discourse and representation theories.

Foucault mainly focused on the role of discourse in producing meanings in historical context. Moreover, he talked about representation of knowledge and how these representations are shaped and given meaning within a specific context (Patterson, 1989, p. 84), (Hall, 1997, p. 4). Foucault used and discussed the concepts of discursive practices and discursive formation in his work Archaeology of Knowledge (Hobbs, 2008, p. 9), through which he aimed "to engage in a pure description of discursive events, which treats the material in its original neutrality, serving as a horizon for the investigation of the unities constructed within it" (Diaz Bone \& et. al, 2008, p. 10).

Archaeologically, Foucault was interested in studying the rules that determine which statements are accepted as meaningful and true in a specific historical period (Jorgensen \& Phillips, 2002, p. 13). In that sense, he defines the discourse as follows:

"We shall call discourse a group of statements in so far as they belong to the same discursive formation [...Discourse] is made up of a limited number of statements for which a group of conditions of existence can be defined. Discourse in this sense is not an ideal, timeless form [...] it is, from beginning to end, historical - a fragment of history [...] posing its own limits, its divisions, its transformations, the specific modes of its temporality" (Foucault, The archaeology of knowledge and the discourse on language, 1972, p. 117).

Foucault also argues that discourse creates truth or truth effects, and sometimes specific discourses in specific contexts have the power to convince people to accept statements as true. (Whisnant, 2012, p. 6). And he views the truth as "a system of procedures for the production, regulation, and diffusion of statements" (Jorgensen \& Phillips, 2002, p. 14).

Besides to his archeological study of truth and dominant discourse in a specific periods, Foucault provided a genealogical study of the relation between power and knowledge, according to him, power must not be seen as completely oppressive, but it must be perceived as a productive (Jorgensen \& Phillips, 2002, p. 13), since it "induces pleasure, forms knowledge, and produces discourse" (Foucault, 1980, p. 119).

Foucault also claims that not just the truth is created by discourse, the subject also is created by discourse. In his work archaeology of knowledge, "Foucault abandons the notion of a sovereign subject (Diaz Bone \& et. al, 2008 , p. 10), and he sees that the subject is decentered, the view which is very different from the standard Western understanding of the subject as an autonomous and sovereign entity (Jorgensen \& Phillips, 2002, p. 15).

Accordingly, in his book of discipline and punish, Foucault showed that "it is through discourse (through knowledge) that we are created; and that discourse joins power and knowledge, and its power follows from our casual acceptance of the "reality with which we are presented" (Foucault, 1977).

Drawing on works of Foucault, Clayton Whisnant explained number of functions for discourse proposed by Foucault, the first function is that discourse constitutes the world, and the world is built socially in our minds through interaction between experience and education, in this sense it is a virtual world full of ideas and emotions, it is not just material world shaped by atoms and energy. The second function is that the discourse also creates knowledge and truth, which is not existing separately from language, some discourses in certain situations have the power to persuade people to accept statements as true. Furthermore, Foucault expressed that discourse provides power to the speaker to be believed, some discourses allow for the certain individuals to speak the truth, or to be believed when they speak about certain subjects, the thing that gives them authority to 
recommend courses of actions or ways of behavior. (Whisnant, 2012, pp. 6-7).

\subsection{Discourse and Media}

As mentioned previously Foucault do not deny the existence of material world, but he argues that it is the people who assign meaning to things, and from here we reach to the relation between media and discourse, media is pervaded and full of discourses, the thing that describe the media as representations (Hobbs, 2008, p. 9).

In his works, Foucault focused on discursive practices which are "actions taken as a part of the real world application of a discourse", then he explained how a "discourse is applied to the social world", within discursive formations that contain "system of thought, the rules, the institutions and the things", So he talked about “"regimes of truth', supported by discursive formations, that are made true through 'discursive practices', he gave examples on discourse in the medical field regimes of truth within "institutional settings" like hospital. From here some scholars talked about mass media within institutional and discursive formation or context like media organization and news or broadcast room (Hobbs, 2008, p. 11).

In media, Journalists admit to communicate truth objectively to the public, even though they operate within framework of discourse that affects the way through which events, accidents and objects are represented by mass media, so it is argued that media texts are full of with discourses that frame and describe the events and actions that had been represented, and materialized as a result of discursive practices of the Journalist. So how much the journalist is committed to represent the truth, but the truth can never be obtained and represented in its pure, since the journalist is constraint with discourse (Hobbs, 2008, p. 11).

So Foucault indicated that it is discourse that communicate the truth and produce knowledge not the subject, who in his production of texts is operating within framework of discursive formation and the regime of truth, taking in consideration historical context and culture. According to this logic the discourse also produces the subject, who must submit to the rules and conventions of the discourse and hold the knowledge that the discourse creates (Hall, 1997, p. 46).

A line with these arguments about discourse and subject, the journalist in media organization is the subject that is created by discourse and works according to its intangible constraints. And he must be influential with functional tools of the media, since his discursive practices in media have the power to make the truth (Hobbs, 2008, p. 12).

Depending on Foucault's idea about creation of regimes of truth, a lot of scholars in their works concluded that "Societies discursively produce, circulate, and consume representations of X, constructing what are often called 'regimes of truth' or 'knowledge.' These discourses are comprised of signifying sequences that constitute more or less coherent frameworks for what can be said and done.", for example, Edward Said in his work of Orientalism showed how "the British and French societies constructed 'truth claims' about the supposed innate and inferior qualities of non-white, non- Christian, 'Oriental' people" (Dunn, 2008). Roxanne Doty also in her work of 'Imperial Encounters (1996)' focused on historical representation through comparing the "asymmetrical encounters between Great Britain and colonial Kenya with representations of the Philippines by the United States within its own imperial project" (Doty, 1996).

Kevin Dunn also was interested in his work of 'historical representations' to show how names, meanings, and characteristics are attached to the world around us. He focused on the mechanism of knowledge and identity, and how they change across time and space, giving the following example:

“For instance, understanding that this is a 'tree,' that is a 'book,' and I am a 'man' presumes access to commonly shared structures of knowledge about objects such as trees, books, and men. But these naming practices might mean something different (or perhaps nothing at all) to people living in different cultures or historical eras. A tree might be a natural resource to be preserved, a commodity to be harvested, a living soul force to be honored, or an embodiment of the spirits of the dead to be worshipped. So it becomes important to understand that representations are historically and contextually contingent." (Dunn, 2008, p. 78)

Dunn argues that "Representations are inventions based on language, but they are not neutral or innocuous signifiers, because they enable actors to 'know' the object and to act upon what they 'know,' representations have very real political implications. Certain paths of action become possible within distinct discourses, while other paths become unthinkable" (Dunn, 2008, p. 79).

Zehfuss also mentioned that even if there were a real, we could never access to it other than through our representations. As a result, what is conceptualized as real that in turn limits our constructions, is itself an effect of representations (Zehfuss, 2004, p. 196). Moreover, "Reality is unknowable outside human perception, and 
there is never only one authority on a given subject". As Friedrich Nietzsche noted, and quoted by Dunn 'There are no facts in themselves. It is always necessary to begin by introducing a meaning in order that there can be a fact' (Dunn, 2008, p. 79).

According to Roaxanne Doty, International relations are inseparably linked with discursive practices that put into circulation representations that are accepted as truth. Analyzing these practices examine how certain representations stimulate the production of knowledge and identities, rather than uncovering of fundamental truths that have been hidden (Doty, 1996, p. 5).

So through representations, media and discursive practices of the journalist challenge the international institutions to take an action in response to the truth that they communicate to the public. The aim of the media is to bring the attention of the public to the humanitarian crisis, creating debates among public which in turn encourage the policy makers to call for change. So the journalist realize that the discourse of media in case of humanitarian disasters and violence aims to "simplify a complex international incident without trivializing human suffering while also bringing to the fore key political questions about these events", as well as it aims to present the disaster and conflict in a way that let watcher who lives in other countries with different social and cultural backgrounds to realize that this event is up normal and requests action (Lynsey Chutel, 2014, p. 6). Thus the journalist keep these objectives and discourses in his mind when he take a photo, or write a news report.

Besides to representation, visual imagery can be approached from a range of theoretical positions (Campbell, Poststructuralism, 2010, p. 242). In that regards, Gillian Rose stated that most of meaning is conveyed by visual images, which presented to us through visual technologies in form of newspaper pictures, snap-shots, "images offer views of the world; they render the world in visual terms. But this rendering, even by photographs, is never innocent. These images are never transparent windows on to the world. They interpret the world; they display it in very particular ways" (Rose, 2001, p. 6).

Rose made a distinction between vision and visuality, "Vision is what the human eye is physio- logically capable of seeing", while "Visuality, on the other hand, refers to way in which vision is constructed in various ways: 'how we see, how we are able, allowed, or made to see, and how we see this seeing and the unseeing therein" (Rose, 2001, p. 6), visual imagery occupy important place in international politics since it is one of the fundamental ways through which news from distant is brought and conveyed home. (Campbell, 2010, p. 243)

Moreover, these visual images as Edward Said argues, contributed to development of an 'imagined geography' in which the dichotomies of the West/East, civilized/barbaric, North/South, and developed/underdeveloped have been prominent. (Said, 1978) cited in (Campbell, 2010, p. 243) As it will be observed in the following cases, the visual humanitarian images in Palestine represent dichotomy of occupied/occupier, victim/terrorist. innocent/violence.

However, David Campbell asserts that interpretation is inevitable and unavoidable in post-structural approach, which maintains that through understanding the unaware and unfamiliar is rendered in the term of familiar. And accordingly "nothing outside of discourse, even though there is a material world external to thought" (Campbell, 2010, p. 243).

\subsection{Discursive Practices and Constitution of Identity}

So depending on the previous analysis of subject and discourse, it is concluded that Post-structuralism assume that subject is partially constituted by discourse, there is nothing outside of discourse, and discursive practices contribute in construction of system of knowledge, social relations and social identity (Jorgensen \& Phillips, 2002, p. 67), when say social identity it means "sets of meanings that an actor attributes to itself while taking the perspective of others, that is a social object". (Wendt, 1994, p. 385)

From here this paper is linking between discursive practices and representations of Journalists in specific issue with constitution and reproduction of social and role identity of other subjects and actors like states, leaders and non-governmental organizations.

Regards the relation between discursive practices and identity, Campbell talked about the 'performative' constitution of identity which is one of the basic onto-political assumption of "deconstructive thought" which "rather than viewing identity as either given by intentional human activity or granted by natural extra-human forces, the idea of performativity draws attention to "the reiterative and citational practice by which discourse produces the effects that it names" (Campbell, 1998, p. 25). So he argues that: 
"Discourse of primary and stable identity'; and that the identity of any particular state should be understood as a 'tenuously constituted in time.... through a stylized repetition of acts', and achieved 'not' [through] a founding act, but rather a regulated process of repetition” (Campbell, 1992, p. 31).

In that regard Tamaki argues that identity relies on language for its ontological sustenance. In other words, identity is equal to performing; and when the practice ends, identity disappears (Tamaki, 2010, p. 87).

Wendt argues that discursive practices are one of the factors that form the intersubjective structure shared understandings, or beliefs "social representation", expectations and social knowledge. For example, the "Cold War was fundamentally a discursive, not a material, structure." However, Wendtian constructivism give place for the effect of material structures, but they argued that "intersubjective structures give meaning to material ones, and it is in terms of meanings that actors act" (Wendt, 1994, p. 389).

These acts or as Hopf called 'social practices', have the power to reproduce the intersubjective meanings that constitute the social structures and actors alike, Hopf gave example on how United States took action of intervention in Vietnam, inferring its identity as great power, at the same time its action had maintained and "reproduce the intersubjective web of meaning about what precisely constituted that identity" (Hopf, 1998, p. 178). The state understands and interprets the others' behavior according to the identity it attributes to them, at the same time the state reproduces its own identity through daily social practices. Besides, Hopf pointed out that the producer of the identity is not in control of what it finally means to others, instead the final arbiter of meaning is the intersubjective structure (Hopf, 1998, p. 175).

\section{Empirical Context: "Role of Discourse and Media in Problematizing and Socializing of Palestinian Issue in the Turkish Foreign Policy."}

\subsection{Role of the Journalist in Creating Knowledge and Truth about Events in Palestine}

In the context of the previous theories about discourse and media, three cases related to the Palestinian issue and Arab -Israeli conflict are selected as an example to show how actors, events or issues are problematized and socialized as human crisis in the world politics by contribution of Journalist as subject who creates truth within the discursive formations in media. On the other side, the logic of interpretation- that take in consideration the obvious political consequences of adopting one mode of representation over another- will be used. The three case studies are representations and visual images about Israeli violation of human rights towards three Palestinian young. Their pictures were taken during the tensions and protests that raised up in different Palestinian lands, as a response to the U.S decision to move its embassy from Tel Aviv to Jerusalem and its recognition of Jerusalem as capital of Israel in the end of 2017. At the same time, another case study will be used to show how some issues face more violations of human rights by Israel, but they are not reached by media and their reality is not reflected by representations, consequently, these humanitarian cases became unknown and
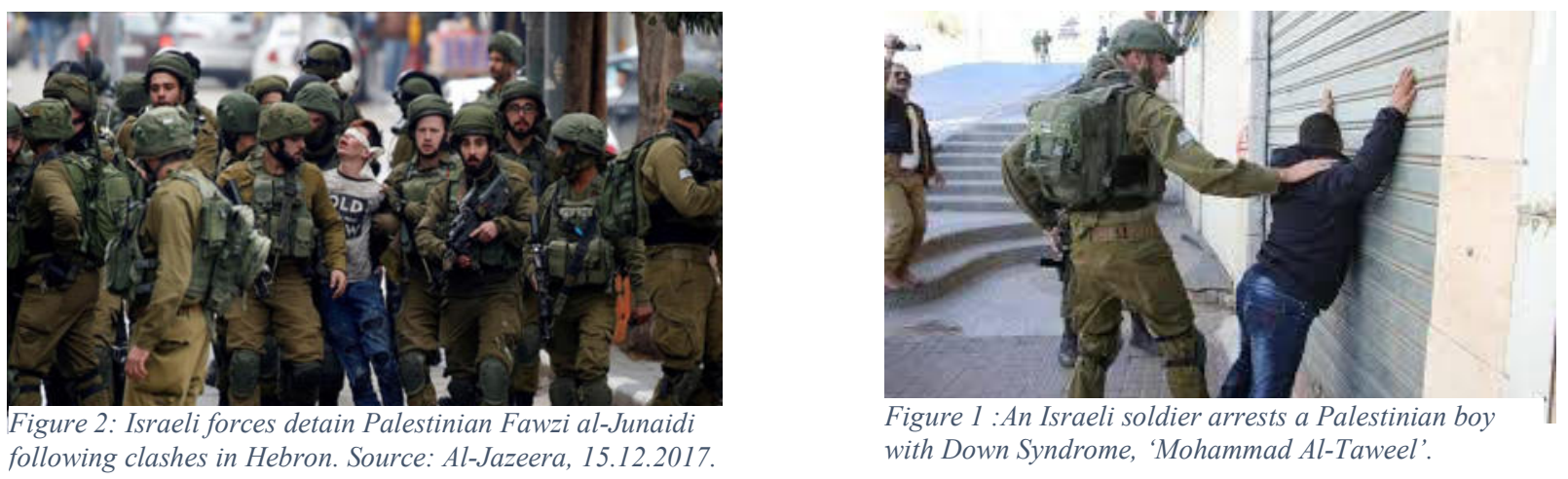

actions that must be taken towards them are unthinkable.

The first image as shown in figure 6.5.1, is interpreted and conveying meaning to the world embodying "the blindfolded Palestinian youth" Fawzi al-Junaidi, who was walking blindfolded by the Israeli soldiers, after catching him on 7 December 2017, in aftermath -as the Israeli soldiers claim- of his participation in protests against decision of U.S Administration to move the American Embassy to Jerusalem and its recognition of Jerusalem as capital of Israel, that was taken on 6 December 2017. Through this mode of representation and visual image, the event interpreted and the issue problematized, the young Palestinian became an object of 
discourse and a myth that embodies the 'Steadfastness of the Palestinians (Aljazeera, 2017), after three weeks from his arresting he was released with security guarantee and returned back to his family on 28 December 2017 (Anadolu Agency, 2018).

Socially, the Palestinian young Fawzi Al-Junaidi became source of inspiration for local and International artists and poets, therefore, after his arrest, his photo became a symbol of fierce Palestinian opposition to the U.S. decision of recognizing Jerusalem as capital of Israel, the thing that drew widespread condemnation and protest from across the Arab and Muslim world" (Anadolu Agency, 2018).

The second visual image in figure 2, was the photo of an Israeli soldier arrests a Palestinian boy with Down syndrome, 'Mohamed Al-Taweel', who was detained for one hour at a commercial complex in central Hebron during protests in Hebron on December 8, 2017, against Trump's decision regard Jerusalem, Photos of AlTaweel's short arrest were widely shared on Arab and foreign social media, where they drew widespread condemnation ( Anadolu Agency, 2017).

The third example about role of media in politics was story of the Palestinian young girl Ahed Altamimi, who became famous by a series of visual images depicted her as hero girl and symbol of Palestinian resistance, her story starts with first image for her through which she was showing her fist for Israeli soldier during a protest held against Israeli settlements at the Nebi Salih village near Ramallah in Palestine in December 2012, as shown in figure 3. That picture which had been taken by photo journalist who works for Turkish Anadolu Agency had created tremendous impression all over the world. Moreover, Ahed had been invited to Turkey and received a courage award (NBC News, 2015), in addition to her meeting with the Turkish Prime Minister then President Recep Tayyep Erdogan, who received Ahed and her mother in his hotel, spoke with them and gave gifts for the family.

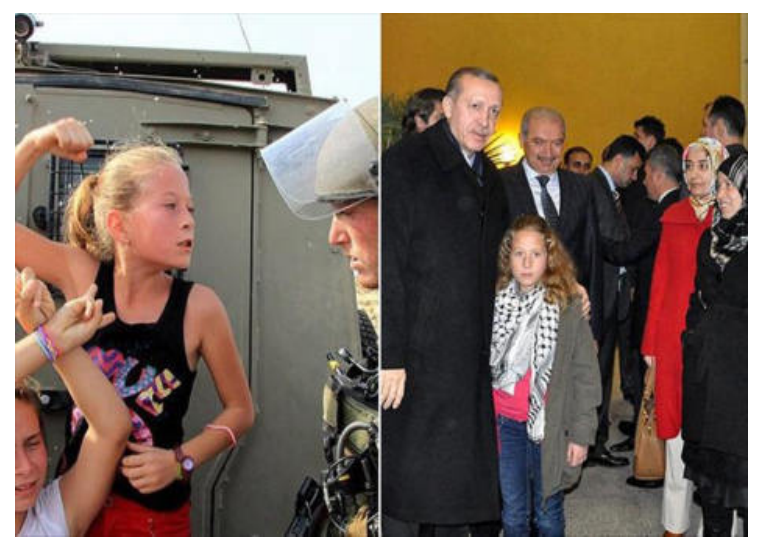

Figure 4: the first photo taken for Ahed Al-tamimi showing her fist to the Israeli soldiers in December 2012

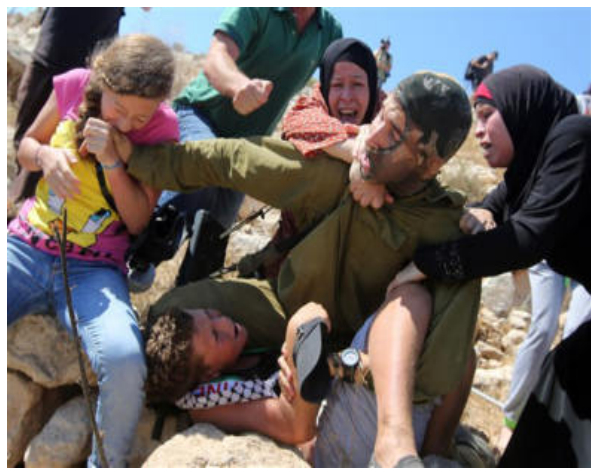

Figure 3 : Picture of Ahed Al-tamimi when she was 14 years old biting and fighting a masked Israeli soldier who was restraining her 12 year old brother, on 28 August 2018

The second visual image of Ahed Tamimi was in 2015, as shown in figure 4, when she was a 14 years old, showing her "biting and hitting a masked and armed Israeli soldier who was thrusting her 12-year-old brother down onto a rock in the West Bank" on 28 august 2015 (NBC News, 2015).The third visual image for Ahed Tamimi, which made her an object of discourse in all over the world, was when she was 16 year old and she "was filmed by her mother, Nariman, shouting at and shoving two soldiers in the driveway of her family home in Nabi Saleh in the occupied West Bank on 15 December 2017" (BBC, 2018). In consequence of that video, Ahed had been arrested after three days (CBS News, 2017), and after 7 months she had been released on 30 July 2018 (ABC News, 2018).

The event itself may not be a big reason for young girl to be loaded to prison, but as an Israeli journalist reported Israeli people felt with humiliating seeing young girl hitting their boys, and the ultra-nationalist ruling coalition demanded punishment.

"She lunged at the soldiers, trying to slap and kick them. She did little damage and the soldiers essentially tried to ignore her. There is only one reason for the soldiers' restraint. They were being videotaped. They knew that if they arrested her or retaliated it would be documented on film and the world would see. So they chose the path of least resistance. However, their refusal to act aroused a 
hornet's nest of anger among Israelis, who saw "their boys" as being beaten down by a mere girl. It was humiliating, and the ultra-nationalist ruling coalition demanded punishment" (Silverstein, 2017)

These three cases still repeated by media, as they became a symbol of Jerusalem crisis narrative, "in which complex political circumstances are interpreted through an established journalistic frame of reference". The journalist here is subject by discourse of media; he created knowledge and truth through the discursive practices and images that he captured. The journalist was operating in boundaries of discourse of media, when he captured the photo he was aware that it will be interpreted in the category of humanitarian crisis and will stimulate the actions of international actors and social institutions. So the discursive practices of the journalist gave him the power to make truth, according to it the outsiders became aware of the Israeli practices towards the Palestinians, and they came from far to dispense charity to victims of Israeli occupation who are facing these violations every day. Instead of repeating this discursive formation in detail each time, the repetition of the three iconic images of the Palestinian young, has established shared understanding of the Israeli violence over the Palestinian children in the domestic and international social structures that affects the thoughts and behavior of individuals, as well as it portrays the asymmetric Palestinian Israeli conflict.

\subsection{Role of Media and Discourse in Creation of Role Identity of Turkey}

In fact, Palestinians in general conceive these events as normal, since they are frequently facing Israeli violence every once a while. At the same time, the rest of the world will not be aware of these incidents, until it had been materialized and constructed as an event through media coverage. As Campbell stated: "these media materializations and discursive formation has effect on 'us' at the same time it gives meaning to 'them', it creates a range of identities us/them victim/savior and are necessary for a response to be organized. This argument is consistent with poststructuralism's reorientation of analysis from the assumption of pre-given subjects to the problematic of subjectivity because it maintains that the event (the emergency or disaster) and the identities of those involved are the effects of discursive practices through which they are brought into being." (Campbell, Poststructuralism, 2010, p. 244)

The logic of interpretation had political consequences, since it became object in constituting identity of actors. The media presented to the world the Palestinian issue in the identity of oppressed/violence, occupied/occupier. However, these materialized events gave space and opportunity for the Turkish government to be a part of discourse formation, through series of discursive practices taken by the Turkish president Recep Tayyeb Erdogan and other non-governmental actors and social institutions. That was when Erdogan invited the two Palestinian youth to Turkey, to show his support to the Palestinian issue, as shown in the following images.

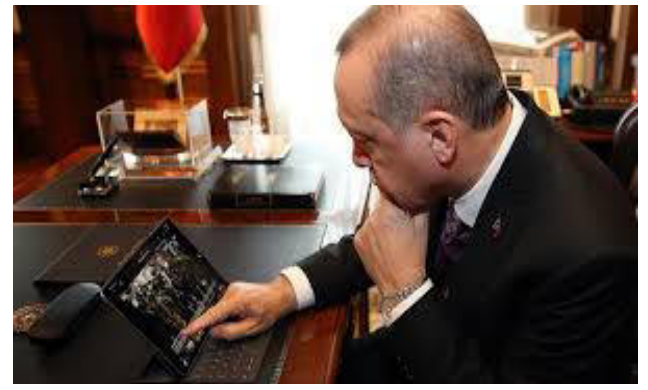

Figure 5: Visual images led to Discursive practices by Turkish government 'the Turkish President views the image of Fawzi Al-Junaidi

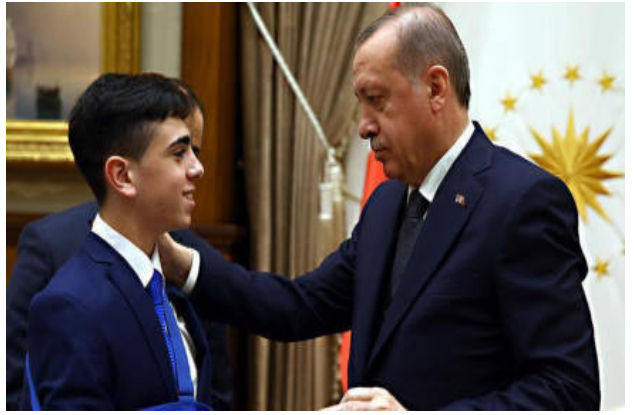

Figure 6: Turkish president invites the Palestinian young 'Fawzi Al-Junaidi' after seeing his image in the media 


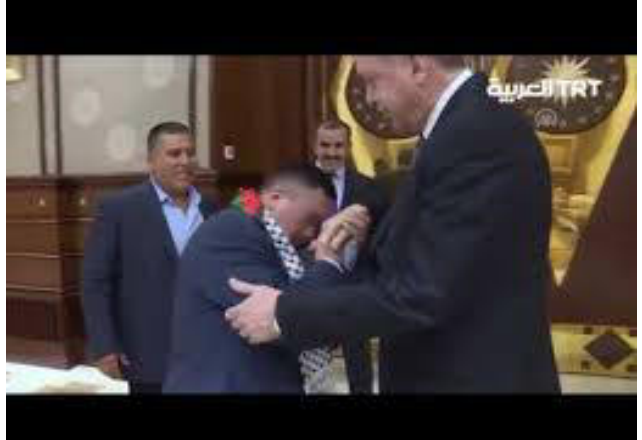

Figure 7: Turkish President Erdogan is seen as father of oppressed Palestinians

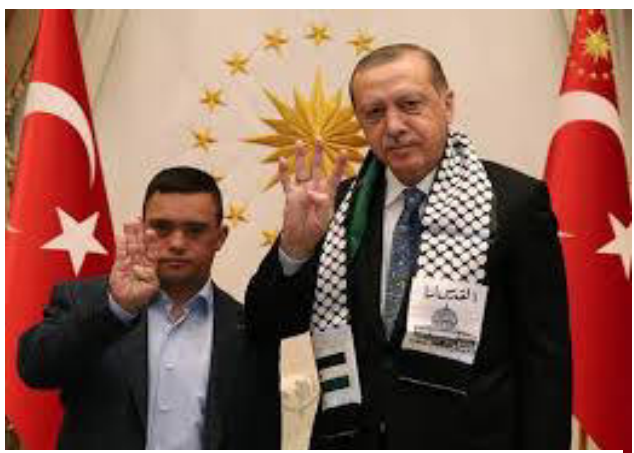

Figure 8: Turkish President invites the Palestinian young Muhammad AL-Taweel

As discussed in the theoretical part, the discursive practices and representations constitute social relations, social identity and knowledge (Jorgensen \& Phillips, 2002, p. 46), in this aspect the discursive practices and actions taken by the Turkish government specially by its president created the relational identity between Turkey and Palestine or the Turkish leader Erdogan and Palestinians in the form of savior/victim. Here, reception of Erdogan for the oppressed Palestinians is interpreted that 'Turkey always beside the oppressed Palestinians'. As a result, the Turkish president was perceived by Palestinians and people of other Arab and Muslim countries as their hero, and they assigned to him the following expressions 'Erdogan is the Leader of Muslim World' 'Erdogan is our 'Khalife'. And that recognition from the other side is necessary to social or role identity to be constituted. Since identity of self is created if the other side recognizes it, it is relational with the other; one cannot enact role identities by oneself, without sharing of expectations (Klotz \& Lynch, 2007, p. 226), and here Erdogan could not define himself as leader of Muslim world if they did not recognize him as their leader. These representational practices towards the oppressed people are contributing in the construction of the Turkish identity as 'regional power'.

So we can see the effect of these representations, as David Campbell framed it:

"Such representations establish the conditions of possibility for state and non-state action with regard to humanitarian crises, especially as they depoliticize the issues and render them best dealt with by humanitarian aid. Significantly, this logic of interpretation encompasses a notion of causality. But, rather than claiming a direct cause-effect relationship between pictures and policy (as in some arguments about the 'CNN effect' in international politics), this focus on the conditions of possibility posits an 'emergent causality' in which elements infuse and resonate across cultural and social domains, creating real effects without being able to specify a direct, causal link. (Campbell, 2010, p. 243)

\subsection{Shared Understanding that Dominate the Social Structures Affects the Meaning and Interpretations Assigned by People to Events.}

Kevin Dunn argues in his work of historical representations, that object or event is perceived by different actors according to the context and shared understanding that dominate the social structure, according to which they interpreted events, thus the representations are historically and contextually contingent. This argument is applied on those two cases. For example, the visual image of the young Palestinian Fawzi Al-Junaidi among Israeli soldiers, normally is seen as a photo of young boy who is taken by force to arrest, different meaning and interpretation are assigned to this image, one of the interpretation for this photo which socially shared between publics is that this boy is a "symbol of resistance against the trump's decision", while the reality is that the young may not intentionally participated in protest, since his father said that he went to the grocery to buy goods for the home, but he had been arrested in a day witnessed great anger against the decision of Trump to move the US Embassy to Jerusalem. So it is the society who assigned him the representation as "Symbol of Palestinian Resistence”. For instance, it is reported in news agency of Anadolu that:

"After al-Juneidi's arrest, a photo of the blindfolded youth became a symbol of fierce Palestinian opposition to the U.S. decision to recognize Jerusalem as Israel's capital" (Anadolu Agency, 2018)

On the other hand, other actors defined and interpreted the event to be an example on terrorism acted by Israel 
against the Palestinian children. For example, we find that selection of these pictures by Erdogan and his related discursive practices, came in consistence with his prominent and repeated discourse about Israel that continuously uses violence against the Palestinian children.

Accordingly, Erdogan used the images in his public meetings to support his claims against Israel. For example, in the image that appeared in figure 9, the Turkish president Erdogan, illustrates the image of the Palestinian young arrested by Israeli forces Fawzi Aljunaidi, during his speech in AK party meeting, in Sivas on 10 Dec 2017.

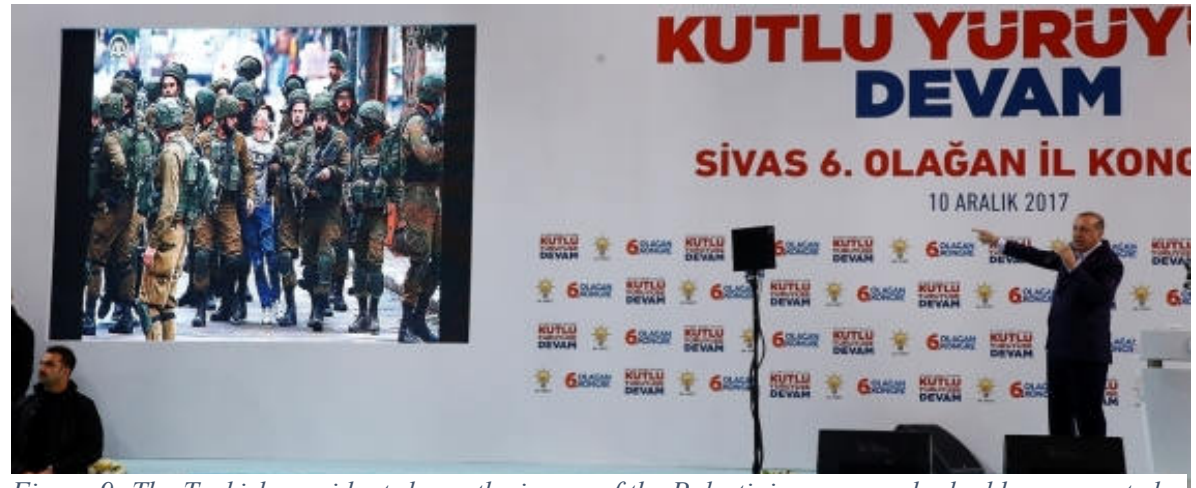

Figure 9: The Turkish president shows the image of the Palestinian young who had been arrested by Israeli forces during his speech in AK party meeting in Sivas on 10 .12.2017, source: Anadolu Agency

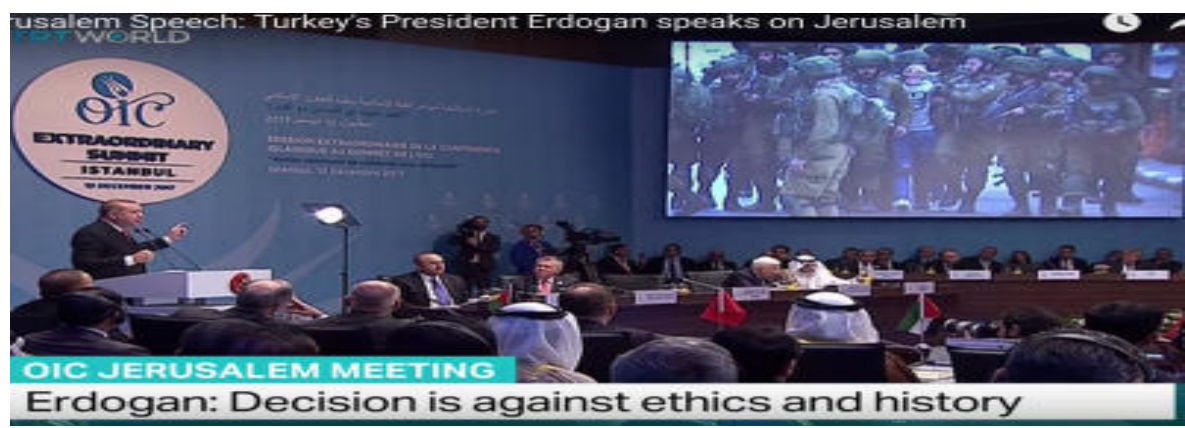

Figure 10: The Turkish president is using the image of Fawzi Al Junaidi to talk about Israeli Terrorist Acts during the meeting of OIC on 13 Dec 2017, Source:TCCB.

Moreover, during the meeting of Organization of Islamic Conference, with the presidents and leaders of Muslim countries, that hold on 13 December 2017, in Istanbul to discuss the measures that had to be taken against the US administration's moving of its Embassy to Jerusalem, Erdogan emphasized that Israel is a terrorist state, and supported his claim by recalling the photos (as shown in figure 10) that show the Palestinian children, Fawzi A1junaidi, who was blindfolded by Israeli occupation forces and Mohammad AlTaweel with down syndrome who being arrested and loaded into iron cages by Israeli soldiers, in addition to Ahd Al-Tamimi the 16 years old girl who being beaten with the butt of a gun and forcefully taken away from her mother. In that regards the president Erdogan made the following remarks:

"What is this if not an occupier or if not terrorist? Is it possible to justify this? Those who have humanity, who have conscience must draw the necessary lessons from these incidents.” (TCCB, 2017)

However, using of these pictures by Erdogan to show how Israel is acting terror towards the Palestinians had been criticized by the West and Israel. For example, the Israeli columnist in 'times of Israel' wrote:

"The power of Junaidi's image has not escaped Turkish President Recep Tayyip Erdogan, who is taking a leading role in the global Muslim opposition to Trump's Jerusalem decision.... On two occasions Erdogan has used the image as a prop when describing Israel as a "terrorist" state.The first was at a rally for his Justice and Development (AK) Party. With an image of Junaidi on a screen, he told the thousands of attendees, "Israel is a terrorist state. We will not abandon Jerusalem to the mercy of a child-murderer state." Again, at the meeting of the Organization of Islamic Countries in Istanbul last 
week, which was called by Erdogan to rally opposition against the US Jerusalem decision, he put Junaidi's image on a screen." (Times of Israel, 2017)

So by means of visual images, the icon of Palestinian steadfastness 'Fawzi al-Junaidi', became subject of speech of the political elites and the Turkish public. Those visual images also became object used by civil organizations as a mean to show their activities in context of humanitarian responsibilities, and their support for the Palestinian issue. In the following photo in figure 11, mayor of Esenler Mehmet Tevfik Goksu in Istanbul received the Palestinian young Fawazi aL-Junaidi and met him with the Turkish public. Besides, the Turkish artists like the players of the popular Turkish TV series 'Payitaht Abdulhamid' -which depicts the Ottoman Empire during the reign of Sultan Abdulhamid- were happy to meet Fawazi al-Junaidi during his visit to the film set. The official Twitter account of the series shared a photo of al-Juneidi with the actors of Payitaht at the film set", as presented in Figure 12 (Anadolu Agency, 2018).

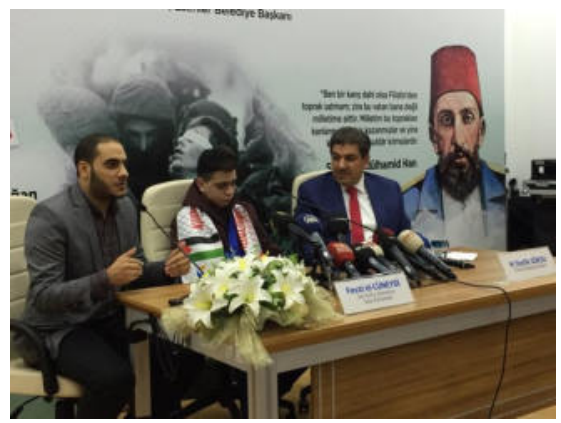

Figure 11: Fawzi al-junaidi welcomed by the Mayor of Esenler in Istanbul. Source: getyimages.com, 16.01.2018

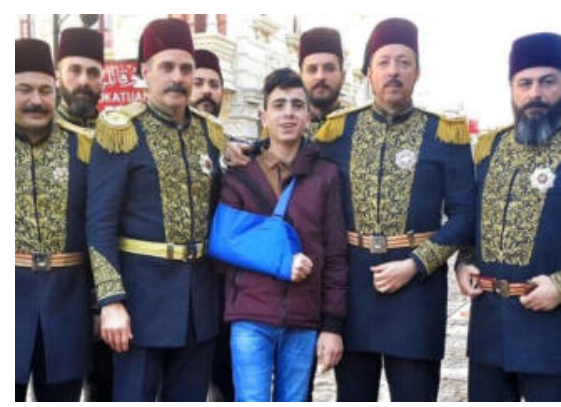

Figure 12: The artists who act role in the series of 2. Abdulhamit are taking photo with al-Junaidi. Source: Anadolu Agency, 17.01.2018.

\subsection{Invisibility and Marginalization of Other Human Crisis in Palestine by Media}

On the other hand, while media and visual images materialize and depoliticize or socialize human crisis and issues, and render the world in visual terms, but this rendering even by photographs is never innocent. As Rose indicated, these images are never transparent windows on to the world (Rose, 2001, p. 6). There may be more severe human crisis that are marginalized by the media, and not materialized or presented to the world through visual images and representations, the thing that can lead to incomplete knowledge. Consequently, the policies drawn upon this knowledge will be unbalanced and biased. For example, during research tour in Palestine with a Palestinian Non-Governmental Organization 'al-Risala', we visited Palestinian lands which are located next to Israeli settlement beside a village of Yatta in Hebron city, as shown in the pictures $(13,14) .{ }^{1}$ These lands classified by Israel as ' $C$ ' area, which means that these areas are under the Israeli administration. Even though, Palestinian communities are living in these areas for decades, and some of them are living before the Israeli occupation, but after Israel defined these areas as closed areas for military training, it prevented the Palestinians from building of houses, (while it is not prohibited for the Israeli settlements as shown in figure 13), even if Palestinians have documents proving their ownership of the lands, like the Palestinian old man in figure 14, who has a document for his ownership of the land, but he could not build normal home, and he built container home that was destructed 11 times by the Israeli authorities. (United Nations , 2013)

\footnotetext{
${ }^{1}$ The pictures were taken during research visit to Massafer Yatta, in July 2018.
} 


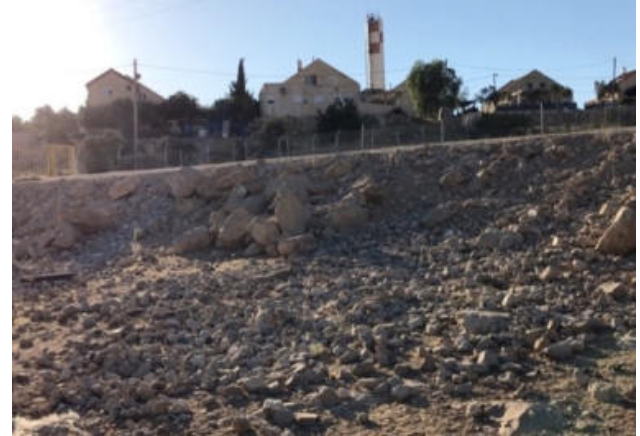

Figure 13: Israeli Settlement besides the Palestinian lands

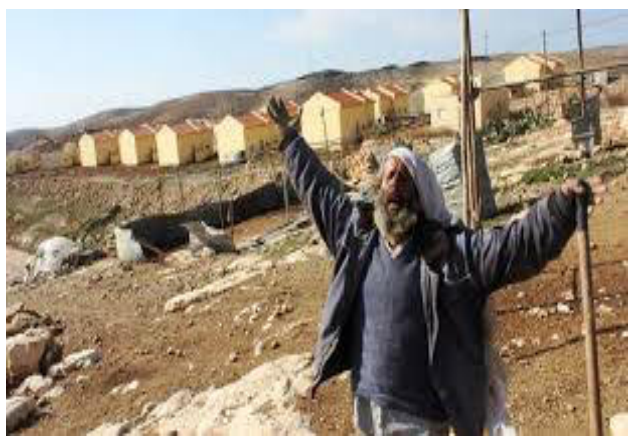

Figure 14: One of the Palestinians who is living in his land beside the settlement refuse to leave it and his home had been destructed 11 times by Israeli authorities

The problem is that Israeli authorities is putting the Palestinians who are living there under pressure to force them to leave their lands. If Palestinians left their lands, the settlements would be expanded to these lands, and by this way illegal settlement will spread and enlarged in Palestine. For that the people who are living in these areas are subject to Israeli practices that undermine their physical security, and decrease their standard of living and increase their poverty. They lack from good services like electric, water and medical services. Israeli authorities said to them, if you move to other areas we will provide you with electric and water. But the Palestinians refuse to leave their lands and accept to live with their children in miserable conditions as shown in figures 15, 16, in order not to allow for the Israeli settlements from spreading. Therefore, those Palestinians are the real resistants who deserve support to live in good conditions at least as the other Palestinians who live comfortably in cities and benefit from good services, either roads or medical services.

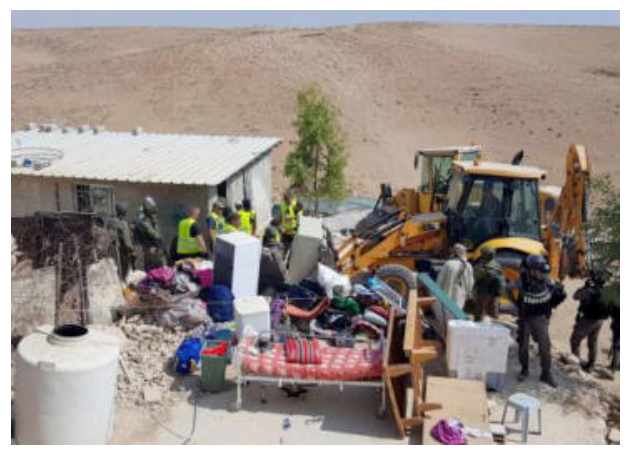

Figure 15: The Israeli Civil Administration destroy homes in Masafer Yatta more than 5 times, the Palestinians still rebuild their homes again Source: UN Office for the Coordination of Humanitarian Affairs, Palestine

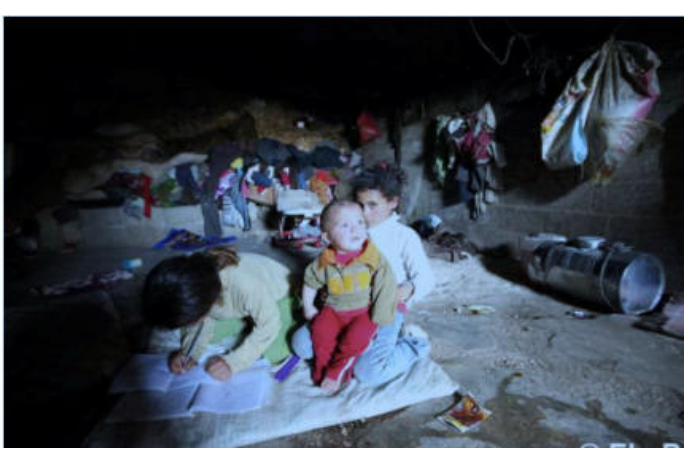

Figure 16: The Palestinians who live beside settlements are living without infrastructure as electric and water Source: UN Office for the Coordination of Humanitarian Affairs, Palestine

So those pictures and images may not include expressive photos about violation of human rights, for that they did not reach to the world as the previous cases of three young Palestinians in Hebron city whose photos reached to hands of the Turkish president Erdogan, as well as the leaders of the whole world. If these pictures had the equal opportunity to reach to the hand of the president of Turkey for example, it would be materialized and became the target of Turkish humanitarian aid and core topic of the discourse of the Turkish leaders, and a new articulation would be constituted regarding the Turkish identity.

The previous cases are examples of how media has a power on determining the context and organization of public knowledge. Which is exercised through restricted topic selection. And some news is interpreted to favor attention to different elite, actors, persons, institutions and nations or world regions. So, those examples support Dijk's claim that the power had a role in production persuasive discourse for public through media. According to 
him, in media discourses such as news, reports and advertising, the agencies combine power in the production of persuasive discourse for public consumption, such news reports may reproduce social structures and stereotypes like blacks, women, or victims (Dijk T. A., 2008, p. 61).

\section{Conclusion}

It is concluded that representations and visual images play a significant role in communicating truth within discourse formation, and reflecting a reality to the policymakers in the Turkish government towards the Palestinian issue, leading to actions and rising of other discursive practices by the Turkish leaders. In turn, these discursive practices entitled new role identity for Turkey among the Palestinians, and the oppressed people in Islamic and neighbor countries. Example of these visual images are photographs of the Palestinian children like Fawzi al-Junaidy, Mohammad al-Taweel, and Ahed al-Tamimi, who exposed to Israeli violence and their photos were problematized and socialized and reached to the hand of the Turkish president Erdogan, who in turn took an action by supporting them and their families, and used their photos during different meetings in shaping his discourse about the Israeli practices against the Palestinians. These discursive practices have fixed the intersubjective meaning about the identity of the Turkish leader as the owner of the Palestinian issue. In return, the others who are Arabs and Palestinians interpreted these discursive practices and attributed identity to Turkey as 'savor of oppressed people', 'regional power', and 'unifier of the Islamic world'. So all of these discursive practices towards the Palestinian issue are examples of the main assumptions of post-structuralism that 'there is nothing outside the text', and 'discourse allows and constrains actions, and makes other discourses possible'. While these visual images had problematized some issues and affected the foreign policy making in the donor countries, but there are more serious issues that did not have the same opportunity to be circulated in the social media and their reality is not reflected by representations, consequently, these humanitarian cases became unknown and actions that must be taken towards them are unthinkable.

\section{REFERENCES}

Anadolu Agency. (2017, December 14). Palestinian with Down Syndrome Abused by Israeli Troops. Retrieved from Anadolu Agency: http://aa.com.tr/en/life/palestinian-with-down-syndrome-abused-by-israelitroops/1004929

United Nations . (2013). Life in a "Firing Zone”:The Massafer Yatta Communities. Case Study Report, United Nations Office for the Coordination of Humanitarian Affairs occupied Palestinian territory.

ABC News. (2018, July 30). Ahed Tamimi, Palestinian protest icon, released from Israeli prison, . Retrieved November 23, 2018, from ABC: https:/www.abc.net.au/news/2018-07-29/ahed-tamimi-palestinian-whoslapped-israeli-solier-released-jail/10049390

Aljazeera. (2017, December 15). Fawzi Aljunaidi icon of Jerusalem's Intifada. Retrieved from Aljazeera:

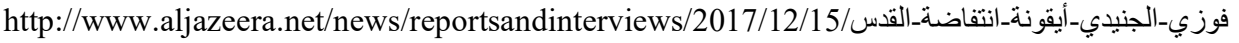

Anadolu Agency. (2018, January 17). President Erdogan receives Palestinian teen Juneidi . Retrieved from Anadolu Agency: http://aa.com.tr/en/middle-east/president-erdogan-receives-palestinian-teen-juneidi-/1034030

BBC. (2018, February 13). Ahed Tamimi: Palestinian viral slap video teen goes on trial. Retrieved November 22, 2018, from BBC: Ahed Tamimi: Palestinian viral slap video teen goes on trial, 13.02.2018. https://www.bbc.com/news/world-middle-east-43032411

Campbell, D. (1992). Writing Security : United States Foreign Policy and the Politics of Identity. Minneapolis: University of Minnesota Press.

Campbell, D. (1998). National deconstruction : violence, identity, and justice in Bosnia . Minneapolis, London: University of Minnesota Press .

Campbell, D. (2010). Poststructuralism. In M. Kurki, T. Dunne, \& S. Smith, International Relations Theories Discipline and Diversity (3rd ed.).

CBS News. (2017, December 21). Palestinian girl lauded arrested for confronting Israeli troops. Retrieved November 22, 2018, from CBS News: https://web.archive.org/web/20171230114524/https:/www.cbsnews.com/news/palestinian-teen-ahed-tamimiprosecuted-israel-attack-soldiers-nebi-saleh/ 
Diaz Bone, R., \& et. al. (2008). The Field of Foucaultian Discourse Analysis: Structures, Developments and Perspectives. Historical Social Research, 33(1).

Dijk, T. A. (2008). Discourse and Power. Palgrave Macmillan.

Dijk, T. A. (n.d.). Political discourse and ideology .

Doty, R. L. (1996). Imperial Encounters: the Politics of Representation in North-South Relations (Vol. 5). London: University of Minnesota Press.

Dunn, K. C. (2008). Historical Representations. In A. K. Prakash, Qualitative Methods in International Relations a Pluralist Guide.

Erdogan, B. (2017). Humanitarian Intervention and the Responsibility to Protect Turkish Foreign Policy Discourse. The Netherlands: Maastricht University .

Foucault, M. (1972). The archaeology of knowledge and the discourse on language. New York: Pantheon. .

Foucault, M. (1977). Discipline and Punish. New York: Pantheon Books.

Foucault, M. (1980). Truth and power. In C. Gordon (Ed.), Power/Knowledge. Selected Interviews and other Writings 1972-1977. New York: Pantheon Books.

Hall, S. (1997). The Work of the Representation. In Representation: Cultural Representations and Signifying Practices.

Hobbs, M. (2008). On Discourse and Representation: Reflections on Michel Foucault's Contribution to the Study of the Mass Media . Annual Conference of the Australian Sociological Association University of Melbourne December 2008. University of Newcastle .

Hopf, T. (1998, summer). The Promise of Constructivism in International Relations Theory . International Security, 23(1), 171-200.

Jorgensen, M., \& Phillips, L. (2002). Discourse Analysis as Theory and Method. . London: SAGE.

Klotz, A., \& Lynch, C. (2007). Strategies for Research in Constructivist International Relations. Armonk, New York, USA: M.E. Sharpe.

Lynsey Chutel. (2014, November 13). The Media as a Non-State Actor in International Relations: A case study of the New York Times' coverage of the Darfur conflict in 2004.

NBC News. (2015, September 12). West Bank Teen Ahed Tamimi Becomes Poster Child for Palestinians. Retrieved December 22, 2018, from NBC News: https:/www.nbcnews.com/news/world/palestinian-posterchild-n425581.

Patterson, T. C. (1989, January). Post-Structuralism, Post-Modernism: Implications for Historians. Social History, 14(1), 83-88

Rose, G. (2001). Visual Methodologies An Introduction to the Interpretation of Visual Materials (1st ed.). London: SAGE Publications.

Said, E. (1978). Orientalism. New York: Said, Vintage Books.

Silverstein, R. (2017, December 28). There is only one reason why Ahed al-Tamimi remains in prison. Retrieved November 25, 2018, from Middle East Eye: https://www.middleeasteye.net/columns/ahd-tamimi-palestineisrael-resistance-1529335057

Tamaki, T. (2010). Deconstructing Japan's Image of South Korea (1st Edition ed.). United States: PALGRAVE MACMILLAN.

TCCB. (2017, December 13). I Call On All Countries to Recognize Al-Quds as the Capital of the State of Palestine. Retrieved from TCCB: https:/www.tccb.gov.tr/en/news/542/87719/tum-ulkeleri-kudusu-filistindevletinin-baskenti-olarak-tanimaya-davet-ediyorum

Times of Israel. (2017, December 18). Two new symbols risk galvanizing protests over Trump's Jerusalem decision, . Retrieved November 25, 2018, from Times of Israel: https://www.timesofisrael.com/two-newsymbols-risk-galvanizing-protests-over-trumps-jerusalem-decision/

Wendt, A. (1994). Collective Identity Formation and the International State. The American Political Science Review, 384-396.

Whisnant, C. (2012, November 9). Foucault \& Discourse :A Handout for HIS 389. 
Zehfuss, M. (2004). Constructivism in International Relations: the politics of reality. United Kingdom: Cambridge University Press. 